\title{
Correction to: Governing uncertainty, producing subjectivity: from Mode I to Mode II scenarios
}

\author{
Limor Samimian-Darash ${ }^{1} \cdot$ Michael Rabi ${ }^{1}$
}

Accepted: 17 August 2021 / Published online: 3 September 2021

(c) Springer Nature Limited 2021

\section{Correction to: Subjectivity (2021) 14:1-18 https://doi.org/10.1057/s41286-021-00116-1}

In the original published article, the below mentioned error was found.

1. The author name Limor Samimian-Darash was misspelled.

2. The below mention funding note was missed to be included:

Funding Note: "This research was funded by Israel Science Foundation, Grant No. 1120/19."

This erratum corrects the same.

The original article has been updated.

Publisher's Note Springer Nature remains neutral with regard to jurisdictional claims in published maps and institutional affiliations.

The original article can be found online at https://doi.org/10.1057/s41286-021-00116-1.

Limor Samimian-Darash

limordarash@gmail.com

1 Federmann School of Public Policy \& Government, The Hebrew University of Jerusalem, Jerusalem, Israel 